\title{
Childlessness Intentions and Ideals in Europe
}

\author{
ANNELI MIETTINEN \\ The Population Research Institute, Väestöliitto, Helsinki, Finland \\ IVETT SZALMA Swiss Centre of Expertise in the Social Sciences (FORS), \\ Lausanne, Switzerland
}

\begin{abstract}
Using data from Eurobarometer Surveys 2001-2011 we examine trends and correlates of childlessness intentions and ideals across Europe over the past decade. We distinguish childlessness as a personal preference (personal ideal number of children is zero) from intended childlessness (intention to have no children) as these reflect somewhat different dimensions of childlessness as a conscious decision. We find that, on average, childlessness as a personal preference is relatively rare in Europe, although in some western European countries a sizeable proportion of young adults express a desire to have no children. Intentional childlessness is slightly more common than ideal childlessness is, since about 11\% of currently childless young adults aged 18 to 40 years in Europe intend to have no children. We analyse factors related to childlessness intentions and ideals on the individual and country levels. A weaker individual socioeconomic position influences the intention to remain childless through various channels, such as unemployment or low socioeconomic status. Associations between individual's social position and ideal childlessness are less clear. Results also indicate that macro-economic conditions do not have a direct impact on intentional childlessness, whereas a higher prevalence of traditional family values in a country is related to a lower likelihood of individuals considering childlessness to be their ideal family form.
\end{abstract}

Keywords: childlessness, fertility intentions, fertility ideals, childfree, Eurobarometer

\section{Introduction}

Although an increasing number of studies focus on low fertility or postponement of childbearing in contemporary Europe, studies on childlessness remain scarce. It is widely assumed that childlessness among young adults is temporary, and is mainly based on a decision not to bear children at a certain time while still planning to have children at some point (Billari, Liefbroer \& Philipov 2006; Kohler, Billari \& Ortega 2002). Recent decades have witnessed, however, a marked increase in lifetime child- 
lessness in many countries. Studies from the Netherlands, the UK, US, and Germany, for instance, show that childlessness among women aged 45 or above is close to $20 \%$ for cohorts born in the end of the 1960s (Dye 2010; Frejka 2008; Rowland 2007; Smallwood 2002). In the younger cohorts, who have not yet passed their reproductive ages, childlessness has increased considerably in the past two decades, reaching over $40 \%$ for women and $60 \%$ for men in their early thirties in some European countries (Miettinen et al. 2014). Although many of the currently childless young adults will go on to have children later, panel studies have shown that a considerable proportion of such "postponers" fail to realize their reproductive plans (Spéder \& Kapitàny 2014; Szalma \& Takàcs 2012; Lainiala 2012).

Most research has related delaying of parenthood to the increase of years spent in education, the difficulties to combine work and family life, or to growing economic uncertainty in Europe, and often assumed that once the obstacles for childbearing are removed, fertility will rise (Billari et al. 2006; Mills \& Blossfeld 2005; Sobotka 2004). Less attention is paid to the role of childlessness as a conscious decision not to have children in explaining fertility differentials. Some scholars do argue that as childbearing decisions are increasingly based on individual preferences and choices, also those who do not wish for children of their own can now more freely express their preferences, leading to higher levels of voluntary childlessness (Tanturri \& Mencarini 2008; Hakim 2000). Recent empirical research suggests that voluntary childlessness is increasing among young adults (Sobotka 2009; Tanturri and Mencarini 2008; Abma \& Martinez 2006; Rindfuss et al. 1988). However, quantitative studies on trends or correlates of voluntary childlessness are still scarce, and in most cases concern only women (Tanturri \& Mencarini 2008; Keizer, Dykstra \& Jansen 2007; Gillespie 2003; Hakim 2000; McAllister \& Clarke 1998).

Here, we focus on childlessness intentions and ideals among young Europeans and report findings from the recent Eurobarometer survey in 2011. We distinguish childlessness as a personal preference (personal ideal number of children is zero) from intended childlessness (intention to have no children) as these reflect somewhat different dimensions of childlessness as a conscious decision. We compare the results for 2011 with those of the previous Eurobarometers from 2001 and 2006 in order to investigate changes in childlessness intentions among Europeans. Previous studies on fertility ideals and intentions have suggested a gradual (Sobotka \& Beaujouan 2014) or marked decline (Testa 2012; Testa 2006; Goldstein, Lutz \& Testa 2003) in average family size ideals over the past two-three decades, but have not specifically looked at childlessness intentions and ideals, or factors related to them. Although the twochild norm is firmly rooted in Europe and most other developed societies (Sobotka \& Beaujouan 2014; Testa 2012), persisting low fertility levels in many countries calls for attention also on fertility desires which diverge from the two-child norm. In a recent study Testa and Basten (2014) examined life-time fertility intentions among childless 
men and women and one-child parents paying attention to the role of perceived economic uncertainties in lowering fertility intentions or increasing their uncertainty. We explore the association of several indicators of individuals' socioeconomic position on intended and ideal childlessness and investigate whether poorer social and economic resources correlate with voluntary childlessness. We also ask how social context and macro-economic conditions influence childlessness intentions and ideals in Europe.

Current fertility trends suggest that childlessness is likely to have a greater role in explaining low fertility levels in many European countries (Miettinen et al. 2014). In the long run, the growing proportions of childless persons will pose extra challenges for future ageing generations, a significant minority of whom will have no adult children or grandchildren to assist them and take care of them. Unwanted childlessness can cause psychological distress and increase loneliness, affecting overall happiness and wellbeing. However, it is not clear to what extent increases in childlessness rates among young adults result from a deliberate choice to remain childless or from postponement of parenthood, nor do we know much about factors contributing to voluntary childlessness. In order to evaluate the potential scope for policy interventions aimed to promote childbearing among young adults, it is important to gain information about trends in voluntary childlessness, as well as understand reasons behind it.

\section{Childlessness intentions and ideals}

Childlessness in contemporary societies is a relatively new research topic and there is no established theoretical framework for studying it. Previous studies have distinguished childlessness as a voluntary decision from involuntary childlessness, although there is considerable ambiguity in how these two are defined. Sometimes the latter is defined narrowly as a physiological inability to have children (infecundity), leaving the former to cover all other variants of childlessness. Some researchers understand voluntary childlessness to mean a conscious decision never to have children, which may or may not be tied to physiological infecundity, or to living in a union (Carmichael \& Whittaker 2007; Park 2005; Hakim 2003; Veevers 1980), while others view not living in a union as one form of involuntary childlessness (Bongaarts 2001). The role of physiological infecundity in distinguishing involuntary from voluntary childlessness has also become less clear with the increasing availability of infertility treatments.

Factors related to lifetime childlessness may differ from those which explain conscious decision not to have children while still being biologically able to have them. Traditional reasons - permanent sterility or living without a partner - may still affect childlessness intentions among young adults, although today's pathways to choosing childlessness can vary considerably (Tanturri \& Mencarini 2008; Keizer et al. 2007). Some may forgo parenthood after a series of decisions to postpone childbearing, since the appropriate moment for a child never arrives. Childlessness may originate from 
postponing parenthood in order to avoid conflicts between parenthood and education or employment, and only gradually evolve into a conscious decision not to have children (Berrington 2004; Smallwood and Jeffries 2003; McAllister \& Clarke 1998). For some, a decision to have no children can be the consequence of considering the current life situation unsuitable for, or incompatible with having children - such as not living in a union, or living with a same-sex partner, or due to health reasons - while others believe that parenting would conflict with other goals in life or life style (Carmichael \& Whittaker 2007; Park 2005; Hakim 2003; Hakim 2000). In these cases, the decision whether to have children or not may be shifting and persons may situate themselves in the middle of the continuum of parenting choice (Letherby 1999). For others, on the other hand, a preference for a child-free life style or an intention to remain childless may be more constant, originating already at an early age (Gillespie 2003; Hakim 2003; Hakim 2000).

Quantitative studies on voluntary childlessness are scarce and information on demographic or social factors associated with it remains scattered and sometimes contradictory. Previous research has suggested that childlessness as a conscious choice is more common among men, highly educated women, urban residents, higher income groups, and among persons who are less religious and hold less traditional family views, or live in more egalitarian relationships (Tanturri \& Mencarini 2008; Abma \& Martinez, 2006; Hakim 2003; Heaton et al. 1999). A preference for childlessness has also been found to be linked with own childhood experiences, living without siblings in particular (Miettinen 2010; Tanturri \& Mencarini 2008; Parr 2005; Kiernan 1989). The role of early socialization in explaining voluntary childlessness is also stressed in Hakim's preference theory $(2003 ; 2000)$ which maintains that individuals develop already at an early age preferences regarding family and work, and those who are more work-oriented are more likely to choose childlessness. Recently, some studies have stressed the role of structural factors and experiences during (young) adulthood, such as increasing difficulties to combine work and family, or increasing opportunity costs related to childbearing as well as growing uncertainty of employment, for explaining childlessness (Testa \& Basten 2014; Miettinen 2010; Tanturri \& Mencarini 2008; Weston \& Qu 2001).

We distinguish intentional childlessness and childlessness as a personal preference (ideal) although we regard them both as dimensions of childlessness by choice. Fertility ideals are considered to reflect personal attitudes and disposition towards (having) children, as well as general societal acceptance of a "childfree" lifestyle, whereas fertility intentions are presumed to reflect actual reproductive behavior, taking into account both individual desires and perceived opportunities and constraints (Hagewen \& Morgan 2005; Schoen et al. 1999; Rindfuss, Morgan \& Swicegood 1988). By separating childlessness intentions and ideals we can evaluate if these two dimensions of voluntary childlessness are associated with the same socio-demographic factors. In most societies, childlessness as a personally preferred life choice has been stigmatized, which is likely to create normative 
barriers for expressing zero children as personal ideal (Merz and Liefbroer 2012; Park 2002; Letherby 1999). Thus we expect that preferences for childlessness are likely to be influenced more by individual and societal norms and values than by the economic or employment situation of an individual. In contrast, socio-economic resources may be more important in predicting intentions to remain childless.

\section{Data and methods}

Fertility preferences have been measured in international social surveys including the ISSP, the Eurobarometer, and in panel studies such as the European Household Panel (Sobotka \& Beaujouan 2014; Testa 2012; Goldstein et al. 2003). In this study, we use the family planning module of the Eurobarometer survey to study childlessness intentions and ideals among men and women aged 18-40 years. Eurobarometer surveys are particularly well-suited for the international comparison on fertility issues as the survey design is controlled and the wording of questions on fertility desires and intentions is equivalent over the years and across countries. Although the number of respondents from each country is not very high, around 1,000 persons, stratified sampling and the use of weights allow us to have fairly reliable estimates on childlessness intentions for all countries as well as for sub-groups broken down by sex, age and parity. For the descriptive part of our study, we have included data from the Swiss Household Panel (SHP, 2011) for Switzerland. SHP2011 survey contained a module on fertility and family planning so that comparable estimates on the prevalence of childlessness desires and intentions for Switzerland could be obtained.

Childbearing (and childlessness) intentions were measured with the Eurobarometer question on the number of children intended. Respondents who did not have children and did not intend to have children (but whose personal ideal may or may not have been zero children) represent intended childlessness. Question on personal ideal family size was used to measure childlessness as a preferred family form, i.e. respondents who regarded zero children as their ideal number of children represent childlessness as ideal. Childlessness ideal (personal ideal 0 children) represents relatively stable (negative) attitudes towards childbearing, which often (but not necessarily) result in a decision not to have children. By contrast, childlessness intentions are assumed to be more reflective of life circumstances, such as poor economic conditions, health concerns, or not living in a (heterosexual) union, which may inhibit childbearing. A person may also prefer childlessness but still have children. The proportion of these 'reluctant parents' among Eurobarometer 2011 respondents was very low, less than $1 \%$, and are not further analysed here.

Obviously, using only two survey questions to measure ideal/intentional aspects of childlessness does not provide a full picture of how individuals end up choosing childlessness. We nevertheless expect that the ability to present comparable 
figures for childlessness intentions and ideals across a number of countries and over time will partly compensate for the limitations in our dependent variables.

Although the questions on personal ideal family size and intention to have (more) children have been almost identical in the Eurobarometer 2001-2011 family planning modules, the response options and their impact on our intended or ideal childlessness estimations deserve some attention. Firstly, it is not always self-evident how uncertainty in intentions and preferences should be treated. Eurobarometer surveys have provided the option "don't know" in the question on personal ideal number of children. In EB2006 and EB2011 surveys an additional option "there is no ideal number, it depends" was included. This diminished somewhat the proportions of "don't know" responses in EB2006 and EB2011 compared to EB2001. Over the survey waves, however, the proportion of ambivalent respondents (either "don't know", or "it depends") in the age group 18-40 years has remained below 10\%. In the question concerning childbearing intentions, "don't know" responses are more frequent, or 12-14\% in EB2006 and EB2011, and as high as 17\% in EB2001. We decided to include uncertain responses into our analyses, regarding them as ideals or intentions above zero. Since our focus is on the explicit ideal or intended childlessness, we assumed that an interpretation of uncertainty as an expression of a preference for, or intention to have children (vs. not to have) but unable to say how many, could be justified. In practice, this reduces the proportions of intended/ideal childlessness in EB2011 and EB2006 a little, and somewhat more in EB2001. We also conducted additional analyses excluding uncertain respondents to examine robustness of our results.

Secondly, EB survey documents do not provide any information on how the interviewers were instructed to treat responses providing a range for an ideal or intended number of children instead of a single value. It is possible that if respondents were pushed to pick only one number, they were more likely to choose socially acceptable values, thus again diminishing the proportions of ideal/intended childlessness.

For analysing our data sets, multiple methods were applied. First, we provide descriptive statistics comparing the frequencies of childlessness ideals and intentions by gender across countries using data from Eurobarometer waves 2001, 2006 and 2011. At the next stage, explanatory models were constructed by applying multilevel logistic regression. Here, we investigate the impact of demographic and social factors on childlessness intentions and ideals using data from Eurobarometer 2011. The argument for using multilevel regression models is that citizens of a given country would not necessarily form views independent from each other according to the dimension of the dependent variable. Applying multilevel models have the advantage of recognizing the partial interdependence of individuals within the same group, or citizens within the same country in our case. In addition, they allow us to investigate the impact of contextual (here country-level) factors on our outcome variables. The analyses are carried out using xtmelogit procedure with STATA12. 


\section{Childlessness ideals in Europe}

We first look at the prevalence of childlessness ideals in Europe. As seen from Figure 1, childlessness as a preferred family form is relatively rare among 18-40-year old adults in Europe, ranging from below 1\% to around 6\% in most countries, with an overall average of $4.2 \%$ for men, and $2.9 \%$ for women in EB2011. Childlessness is rarely considered ideal in many eastern European countries and relatively infrequently $(<=2 \%)$ in Ireland, France and Portugal. In contrast, the proportion of young adults who consider zero children their ideal is considerably higher, around $10 \%$, among men in East-Germany, Austria and Luxembourg, and around 8\% among women in East- and West-Germany and Switzerland. Dutch men show the highest rates of childlessness preferences in Europe in 2011, with 16\% of men in the age group of 18-40 years indicating that they would prefer to have no children. On average, men consider childlessness ideal only a little more often than do women in EU15 countries (6\% vs. $4 \%$ ), while there is no difference between sexes in eastern European countries (men $2 \%$, women $1.6 \%$ ).

The average proportions of young adults who prefer childlessness were almost the same, or $4.3 \%$ for men, and $3.2 \%$ for women in the 2006 Eurobarometer survey (EU27, results not shown). Most of the countries exhibiting higher rates of preferred childlessness in EB2011 (Austria, Netherlands, Luxembourg, West- and East-Germany) had also higher proportions of young adults who considered childlessness ideal in one or both of the previous Eurobarometer surveys in 2001 and 2006 (see also Testa 2006; Goldstein et al. 2003).

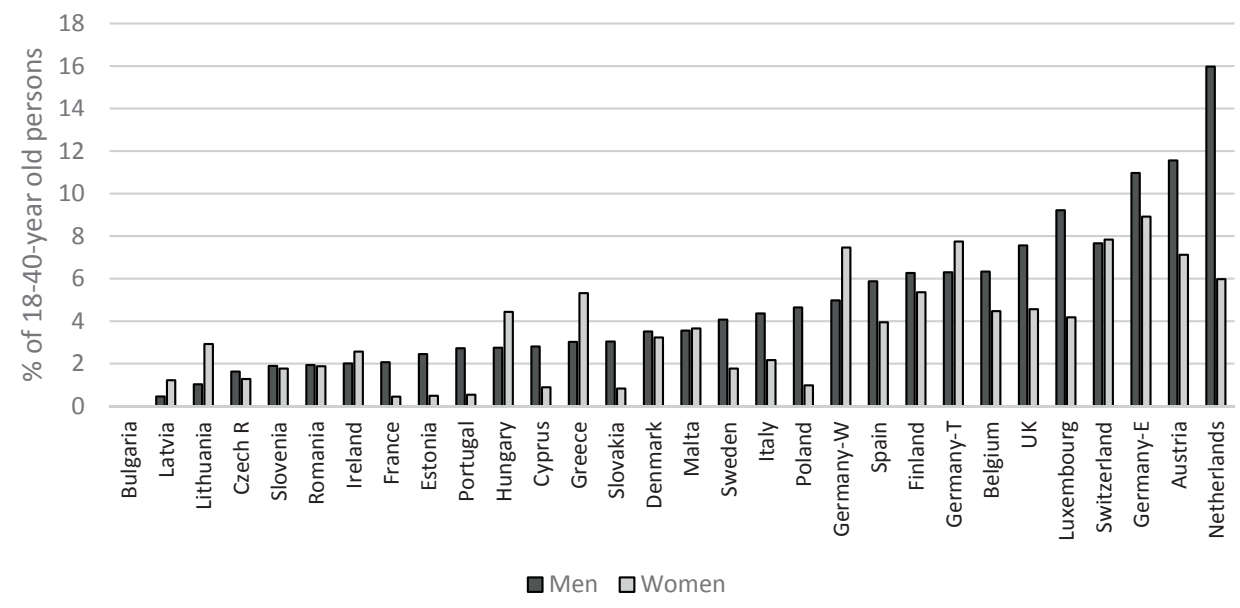

Figure 1. Childlessness ideals among 18-40 year old men and women (\% of all men/women in the age group 18-40 who considered zero children their ideal family size). Eurobarometer 2011.

Source: Eurobarometer 2011 and Swiss Household Panel (for Switzerland). Authors' calculations. 


\section{Intended childlessness in Europe}

In Table 1 we present figures for intended childlessness across countries in Europe, and over the consecutive Eurobarometer surveys. On average, intentional childlessness is not very common among young adults in Europe, although it is more common than childlessness as a preferred family form. Figures from the recent Eurobarometer survey from 2011 show that in most European countries $90-95 \%$ of men and women aged 18-40 years either already have children or intend to have children sometime in the future. On average (EU27), 7\% of men and 5.2\% of women in the age group 18-40 years intend to remain childless. There is, however, considerable country variation in childlessness intentions. The proportion of men in the age group 18-40 years who intend to remain childless is above 10\% in Austria, Spain and Sweden. In East-Germany, Luxembourg, Switzerland and the Netherlands the rates of intentional childlessness among 18-40-year old men exceed 15\% in EB2011. For women, the highest rates of intended childlessness are observed in Belgium, East-Germany, Luxembourg, Switzerland, the Netherlands, and the UK, with values varying between $10 \%$ and $14 \%$. Intentional childlessness is relatively low in eastern and central-Europe, ranging from below $1 \%$ to around $5 \%$ for both men and women. In this region, only Romanian men show somewhat higher childlessness intentions (7.3\%, EB2011).

There is no clear trend in the rates of intended childlessness in Europe over the past decade. On average (EU27), the rates of intended childlessness vary around 7\% for men and around 5\% for women in EB2011 and in EB2006. For EU15, the average rates of intended childlessness are slightly higher, or around $9 \%$ for men and around $7 \%$ for women with no marked change across the three Eurobarometer waves. As with childlessness ideals, countries with high proportions of intentional childlessness in the previous Eurobarometer surveys from 2006 and 2001 (Austria, East and West Germany, and the Netherlands, and in EB2006 Luxembourg) continue to show clearly aboveEuropean average proportions of young adults who do not plan to become parents. However, for men and women Austria and men in West-Germany, rates of intentional childlessness seem to have decreased since the 2006 survey, whereas in Belgium, the Netherlands, and Luxembourg intended childlessness has increased since 2006.

Despite considerable economic and political changes in recent decades there is no sign of an increase in childlessness intentions in the eastern European countries. Rather, as suggested also with the very low levels of childlessness ideals (Figure 1), young women and men in eastern European countries seem to have preserved the social norm that every person (woman) should have at least one child (Regusevskaya et al 2013; Merz \& Liefbroer 2012). The overall decline in mean ideal family sizes (see Testa 2012) in many of these countries thus appears to be a consequence of a decrease in higher parity ideals rather than of an increase in ideal, or intended childlessness.

Southern European countries do not exhibit any clear trend in intended childlessness either. In Greece, a slight upward trend over the past decade appears, and also men 
in Italy and Spain show relatively high values in intended childlessness in the recent EB2011 survey. Intentional childlessness has remained on a relatively low level in northern European countries, with the exception of Swedish men, among whom intended childlessness reached $11 \%$ in the EB2011 survey.

Table 1. Intention to have no children among 18-40-year old persons by gender and country (\% of the age group). Eurobarometer surveys 2001, 2006 and 2011.

\begin{tabular}{|c|c|c|c|c|c|c|}
\hline & \multicolumn{3}{|c|}{ Men } & \multicolumn{3}{|c|}{ Women } \\
\hline & 2011 & 2006 & 2001 & 2011 & 2006 & 2001 \\
\hline \multicolumn{7}{|l|}{ Central Europe } \\
\hline Austria & 13.4 & 22.4 & 11.7 & 9.2 & 16.6 & 13.5 \\
\hline Germany-T & 10.0 & 10.1 & 19.4 & 9.2 & 8.5 & 8.9 \\
\hline Germany-W & 8.5 & 11.2 & 20.5 & 8.6 & 8.4 & 9.3 \\
\hline Germany-E & 15.1 & 5.9 & 15.3 & 11.2 & 8.6 & 7.0 \\
\hline Switzerland & 15.0 & & & 14.6 & & \\
\hline \multicolumn{7}{|l|}{ West Europe } \\
\hline Belgium & 9.8 & 6.2 & 14.2 & 11.7 & 9.8 & 3.9 \\
\hline France & 4.5 & 5.3 & 5.4 & 2.4 & 3.8 & 1.5 \\
\hline Ireland & 3.7 & 7.8 & 13.0 & 3.7 & 7.4 & 10.5 \\
\hline Luxembourg & 16.3 & 7.4 & 6.9 & 12.9 & 8.9 & 5.2 \\
\hline Netherlands & 19.1 & 13.1 & 11.1 & 10.2 & 5.4 & 13.5 \\
\hline UK & 9.8 & 11.6 & 4.6 & 10.0 & 4.7 & 3.0 \\
\hline \multicolumn{7}{|l|}{ Central-East Europe } \\
\hline Bulgaria & 0.8 & 1.1 & & 0.6 & 0.9 & \\
\hline Croatia & & 2.5 & & & 1.1 & \\
\hline Czech R & 3.7 & 6.1 & & 2.6 & 1.2 & \\
\hline Hungary & 5.9 & 5.0 & & 5.6 & 2.4 & \\
\hline Poland & 5.6 & 2.5 & & 2.6 & 1.8 & \\
\hline Romania & 7.3 & 6.6 & & 4.8 & 7.6 & \\
\hline Slovakia & 3.6 & 6.2 & & 1.6 & 6.2 & \\
\hline Slovenia & 2.5 & 2.8 & & 3.0 & 3.0 & \\
\hline \multicolumn{7}{|l|}{ North-East Europe } \\
\hline Estonia & 4.0 & 5.1 & & 0.5 & 1.9 & \\
\hline Latvia & 4.8 & 6.9 & & 3.4 & 6.7 & \\
\hline Lithuania & 4.7 & 0.8 & & 2.0 & 1.5 & \\
\hline \multicolumn{7}{|l|}{ South Europe } \\
\hline Cyprus & 2.9 & 4.7 & & 6.0 & 1.4 & \\
\hline Greece & 5.7 & 2.6 & 2.6 & 8.5 & 2.3 & 2.4 \\
\hline Italy & 9.3 & 6.1 & 5.2 & 4.2 & 7.6 & 5.9 \\
\hline Malta & 6.4 & 10.2 & & 3.7 & 4.6 & \\
\hline Portugal & 5.0 & 8.1 & 5.8 & 4.9 & 4.9 & 3.5 \\
\hline Spain & 10.7 & 8.3 & 7.1 & 4.0 & 7.6 & 4.1 \\
\hline \multicolumn{7}{|l|}{ North Europe } \\
\hline Denmark & 6.1 & 4.6 & 8.4 & 5.5 & 4.8 & 4.4 \\
\hline Finland & 7.0 & 3.2 & 7.3 & 5.3 & 7.9 & 4.6 \\
\hline Sweden & 11.2 & 4.7 & 3.3 & 5.2 & 2.9 & 4.2 \\
\hline $\mathrm{N}$ & 4373 & 4332 & 3180 & 4959 & 5620 & 3495 \\
\hline EU15 & 9.1 & 8.4 & 9.1 & 7.0 & 6.9 & 6.1 \\
\hline EU27 (excl. Croatia and Switzerland) & 7.0 & 6.8 & - & 5.2 & 5.4 & - \\
\hline
\end{tabular}

Note: EU-averages are calculated by using weights for individual countries, not EU27 or EU15 total. Source: Eurobarometer 2001, 2006 and 2011, and Swiss Household Panel (for Switzerland). Authors' calculations. 
Data from the Swiss Household Panel suggest that the central-European pattern of high rates of childlessness intentions is particularly manifest in German-speaking countries. It has been suggested that the low fertility desires observed in these countries could result from the almost three-decades-long period of markedly low fertility in the late 20th century, with young generations growing up in families with only one or two children, and thereby adopting a small-family preference themselves (Lutz et al. 2005; Goldstein et al. 2003). While this socialization hypothesis may in part explain the recent increase of childlessness intentions also in Italy (men), Spain (men) and Greece (women) - countries in which fertility levels fell considerably in the 1980s and have remained low ever since - it is less likely to explain the increase in childlessness intentions in the Netherlands, Belgium, the UK, and Sweden (for men) where a similar drop in fertility has not been observed.

The relatively small increases in proportions of intended childlessness may reflect variation in the share of childless respondents in the surveys over time. Since our measure of intended childlessness included persons who did not have children and who did not intend to have any, underestimation of actual childlessness in the surveys can depress rates of intended childlessness in the total population aged $18-40$ years. The Eurobarometer 2006 is considered to potentially underestimate actual childlessness among respondents especially in Germany, pushing up the values of ideal number of children (Testa 2006). Thus the marked decrease in the intended childlessness rates in EB2006 as compared to EB2001 in Germany (men) could be a consequence of differences in the sample composition. For East-Germany, differences in the sample size (1,000 persons in EB2001, but 500 in the later surveys) may have also contributed to the considerable fluctuation in the rates of intended childlessness (see also Testa 2006).

Compared to the EB2006 survey, the proportion of actual childless respondents has increased in most western European countries in the recent EB2011 survey. This concerns also East- and West-Germany, Luxembourg, the UK and the Netherlands and, to a lesser extent, Austria and Sweden. The growth of intentional childlessness from 2006 to 2011 (in East-Germany, Sweden, the Netherlands and Luxembourg, but not in Austria or WestGermany (men), where intended childlessness has decreased since the EB2006 survey) may thus partly result from changes in the sample composition. Likewise, substantial decreases in the proportions of currently childless respondents in the EB2011 survey compared to the previous EB2006 survey may contribute to the fact that intended childlessness has remained low or even decreased in Ireland, Hungary, Poland and Portugal since 2006.

Given that the proportions of intentionally childless are likely to reflect in part differences in the proportions of childless respondents in each national surveys, in Figure 2 we depict the proportions of currently childless women and men (of all respondents aged 18-40 years) in EB2011 as well as the proportions of persons (of all respondents in the age group) who do not intend to have any children. This allows us to see how large a fraction of current childlessness is explained by definitive (intentional) childlessness. 
For the majority of childless young Europeans, current childlessness appears to be temporary, caused by a postponement of childbearing to a more suitable time (Figure 2). On average (EU27), 11\% of currently childless women and men aged 18-40 years intend to remain childless. Among EU15 countries, definitive childlessness is somewhat on a higher level, with $14 \%$ of childless men, and $15 \%$ of childless women intending never to have children. The share of intentional childlessness is notably high among childless women in the UK, Belgium, East-Germany, the Netherlands and Luxembourg, where $17-27 \%$ of the currently childless women intend to have no children. For men, definitive childlessness among currently childless persons reaches $17-27 \%$ in East-Germany, the Netherlands, Luxembourg, Austria, and Sweden.
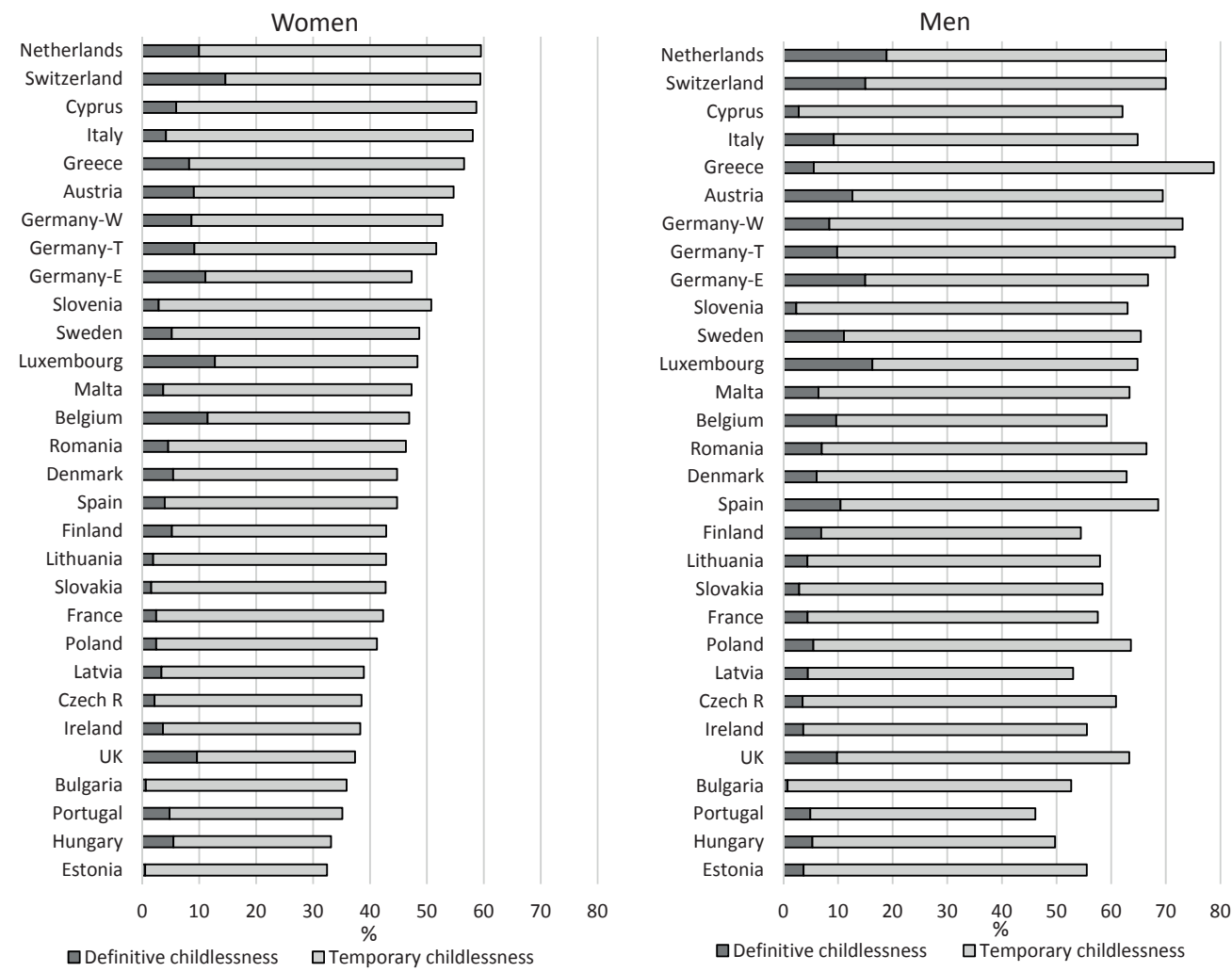

Figure 2. Proportions of currently childless women and men of all women/men aged 18-40 years, divided into temporary and definitive childlessness, Eurobarometer 2011.

(Countries are arranged in accordance with the proportion of childless women among the respondents)

Definitive childlessness $=$ proportion of childless persons who intend to have no children (of all persons in the age group)

Temporary childlessness $=$ proportion of childless persons who intend to have children in the future (of all persons in the age group)

Source: Eurobarometer 2011 and Swiss Household Panel 2011 (for Switzerland). Authors' calculations. 


\section{The impact of individual and country-level factors on child- lessness intentions and ideals}

Next, multilevel logistic regression random intercept models were applied to investigate the effects of individual- and country-level factors on intended and ideal childlessness among 18-40-year old childless adults, using data from the Eurobarometer 2011 ${ }^{1}$. Multilevel models are appropriate because of the hierarchical data structure with individual respondents being nested within countries. Given that national samples in the Eurobarometer surveys are relatively small, and rates of intended and ideal childlessness are low in most countries, performing separate analyses to investigate factors associated with childlessness intentions or ideals for each country would not be meaningful. While allowing us to draw conclusions on individual characteristics related to intentional/ideal childlessness using pooled data, multilevel models provide an opportunity to incorporate country-level factors into our analyses. Our analytical sample consists of 2,701 childless men and 2,131 childless women from 27 countries (Germany is here treated as united).

By including contextual data we aim to investigate whether macro-economic conditions or normative climate on societal level influence young adults' childbearing intentions and ideals over individual-level effects of own employment situation, socioeconomic background or education. It has been suggested that poor economic conditions on macro-level could depress fertility intentions among all young adults in a country, not only those who are themselves affected by unemployment or temporary employment contracts (Testa \& Basten 2014; Goldstein et al. 2003). Likewise, a societal acceptance of non-traditional family forms should provide more freedom to express fertility attitudes and desires which diverge from the general norm, manifested in higher levels of voluntary childlessness in countries with less conservative family ideologies (Merz \& Liefbroer 2012).

As individual-level demographic factors, we use gender, age, union status (living in marital/cohabiting union - not in union), and place of residence (large town/city other) which previous research has frequently shown to affect fertility behavior and attitudes. Individual-level socio-economic indicators include educational attainment (low= ISCED 0-2; middle-level=ISCED 3-4; high=ISCED 5-6), self-assessed socioeconomic status ( 5 categories from low to high) and a measure of the financial situation of the household (4 categories ranging from "very good" to "very bad", a higher value indicating poorer conditions). We created a four-category measure for employment status to cover different kinds of uncertainties related to employment. Our measure combines information about the economic activity of the respondent as well as about perceived uncertainty of personal employment situation differentiating between those who are employed and who regard their employment situation as good

\footnotetext{
${ }^{1}$ We could not use pooled data from the EB waves 2001, 2006 and 2011 because they did not include all variables of interest, and the educational level was measured differently.
} 
or rather good (1), those who are employed but regard their employment situation as bad or rather bad (2), unemployed or inactive persons (3), and students (4). We expect that poorer socioeconomic resources, measured by a lower educational level, lower socioeconomic status, poor attachment to the labour market (not being employed, or employment situation poor), and dissatisfaction with the financial resources of the household are associated with a higher likelihood of intending to remain childless as well as preferring childlessness (voluntary childlessness). However, since we presumed that fertility intentions are likely to reflect perceived opportunities and costs of childbearing more than fertility ideals do, we expect that the association between poor socioeconomic resources and childlessness intentions is stronger than their association with childlessness ideals. Previous research has suggested that the effects of economic activity and educational attainment, in particular, on childbearing intentions and behaviors vary between men and women, and therefore we tested for interactions between gender and socioeconomic resources.

As country-level factors, we incorporated information about the rates of female tertiary education, the economic situation of the country, and prevalence of traditional family values (see Table 2 for country-level factors). The proportion of women with tertiary level education in 2010 (in the age group 25-34 years, drawn from Eurostat Educational Attainment Statistics) measures overall levels of educational attainment among young adults, as well as women's position in a country. We expect that a high overall level of educational attainment in a country is related to a higher acceptance of non-traditional family forms, including childlessness as a conscious choice, and thus, is positively associated with the intention to remain childless, as well as with the preference of 0 children. In addition, increasing female education is also likely to increase general awareness of the (potential) conflict between work and family life, which in turn can decrease childbearing desires and intentions among young adults. Unemployment rates for 15-39-year olds in 2011 (drawn from Eurostat Labour Force Statistics) measure both the economic situation of a country as well as, specifically, the employment situation of young adults. We assume that a higher unemployment rate in a country is related to increased likelihood of individuals deciding to remain childless, while its association with preferring childlessness is likely to be less strong. In preliminary analyses we also tested a more direct measure of the economic situation in a country (change in GDP during 2008-2010), but found no significant effects.

The prevalence of traditional family values is measured by the proportion of respondents agreeing with the claim "children are important for a successful marriage", in European Values Study 2008-2010. We expect that this measure is positively related to childbearing intentions (e.g. intention to have at least one child) and ideals above zero. We also included a fourth country-level factor, a dichotomy for state-socialist countries and others, to control for the low prevalence of intentional or ideal childlessness in eastern European countries and to study independent effects of other country-level 
factors. We assume that the impacts of unemployment rates and the level of female tertiary education are more apparent for birth intentions rather than for fertility ideals while at the same time social norms are more important predictors of childlessness ideals than they are for intended childlessness.

Table 2. Overview of the country-level factors used in the multi-level analyses.

\begin{tabular}{|c|c|c|c|c|}
\hline & & $\begin{array}{l}\text { Women with tertiary } \\
\text { level education, \% } \\
\text { (in age group } \\
25-34 \text { years) }\end{array}$ & $\begin{array}{l}\text { Unemployment } \\
\text { rate among } \\
15-39-y e a r \\
\text { olds }\end{array}$ & $\begin{array}{c}\text { Importance of } \\
\text { children for a } \\
\text { successful } \\
\text { marriage, } \% \\
\text { agreeing }\end{array}$ \\
\hline \multirow[t]{2}{*}{ Central Europe } & Austria & 22.6 & 5.9 & 51.4 \\
\hline & Germany-T & 27.5 & 8.2 & 45.6 \\
\hline \multirow[t]{6}{*}{ West Europe } & Belgium & 49.4 & 11.4 & 49.0 \\
\hline & France & 47.2 & 12.4 & 63.6 \\
\hline & Ireland & 54.7 & 17.1 & 58.0 \\
\hline & Luxembourg & 46.0 & 5.6 & 55.3 \\
\hline & Netherlands & 43.6 & 5.4 & 45.4 \\
\hline & UK & 43.6 & 10.9 & 50.2 \\
\hline \multirow[t]{7}{*}{ Central-East Europe } & Bulgaria & 35.6 & 12.6 & 78.1 \\
\hline & Czech R & 25.4 & 8.7 & 62.8 \\
\hline & Hungary & 31.2 & 13.5 & 77.9 \\
\hline & Poland & 44.7 & 11.9 & 57.9 \\
\hline & Romania & 22.6 & 10.0 & 68.5 \\
\hline & Slovakia & 29.8 & 17.3 & 80.9 \\
\hline & Slovenia & 40.3 & 9.7 & 68.9 \\
\hline \multirow[t]{3}{*}{ North-East Europe } & Estonia & 48.3 & 18.6 & 61.2 \\
\hline & Latvia & 45.6 & 22.7 & 65.6 \\
\hline & Lithuania & 54.8 & 20.8 & 58.4 \\
\hline \multirow[t]{6}{*}{ South Europe } & Cyprus & 53.7 & 8.0 & 81.7 \\
\hline & Greece & 36.0 & 17.6 & 77.2 \\
\hline & Italy & 25.1 & 12.7 & 60.6 \\
\hline & Malta & 28.1 & 8.0 & 55.9 \\
\hline & Portugal & 31.5 & 12.9 & 48.0 \\
\hline & Spain & 46.4 & 24.0 & 62.8 \\
\hline \multirow[t]{3}{*}{ North Europe } & Denmark & 44.3 & 9.8 & 34.8 \\
\hline & Finland & 47.8 & 11.1 & 45.7 \\
\hline & Sweden & 48.9 & 12.4 & 45.9 \\
\hline
\end{tabular}

Source: Eurostat Educational Attainment 2010 (the proportion of women with tertiary level education in the age group 25-34); Labour Force Statistics 2011 (unemployment rate of 15-39-year olds); European Values Study 2008-2010 (the proportion of respondents agreeing with 'children are important for a successful marriage'). Authors' calculations. 
Table 3a presents the estimations obtained from multilevel models for intended childlessness. Our dependent variable is dichotomous with $0=$ respondent intends to have children, $1=$ intends to have no children. Table $3 \mathrm{~b}$ shows the same for childlessness ideals, with a dichotomy $0=$ respondent's ideal $1+$ children, $1=$ ideal 0 children. Model 0 is the intercept-only model, testing for the country-level variance, and in the column "Model I" we present the effects of each individual socioeconomic and country-level variable on fertility intentions and ideals on their own, adjusting for demographic factors (gender, age, place of residence, union). Model I thus summarizes results from several models. As the socioeconomic factors are likely to overlap at least partly, Model I allows us to see their independent associations with childbearing intentions and ideals. Model II then includes all individual-level factors in the same model, and Model III and Model IV further include country-level factors.

For childbearing intentions, Model 0 shows a statistically significant country-level variance $(0.292, \mathrm{p}<0.01)$, justifying also the use of multilevel models (Table $3 \mathrm{a})$. Model II shows which of the individual-level characteristics predicted the intention to remain childless once they were included in the analyses jointly. Increasing age and not living in a union increased the odds for intending to remain childless while differences between men and women or between urban or non-urban residents were not, or only marginally statistically significant. Education was negatively associated with the odds of intending to remain childless, i.e. less-educated persons were more likely to intend to remain childless compared to middle-level or highly educated persons. Once we controlled for self-assessed social status, the impact of middle-level education became statistically insignificant. Since the effect of education reflects also differential pace in the postponement of parenthood, the negative effect of higher education on childlessness intentions is partly a result of selection. In each age group, there are more persons who are yet to start their family formation process, and intend to have children among the highly educated persons compared to less-educated men and women, among whom many who intended to have children have already become parents.

Uncertainty of employment was significantly related to birth intentions. Unemployed or inactive persons had lower odds of intending to become parents compared to employed persons who regarded their work situation as good. The negative impact of a bad employment situation (employed but perceiving own employment situation poor) on childbearing intentions was statistically significant only among men (results from a model including gender interactions are not shown), and its impact diminished after including measures for financial situation of the household and social strata in the model. This suggests that uncertainties related to employment among those who are employed influence birth intentions through their impact on household finances, which in turn are related to how people position themselves in the social scale. However, higher socioeconomic position increased intentions to become a parent independently of the financial situation of the household (Table 3a shows only the final models). We 
also tested for gender differences in the impacts of socioeconomic status, education and employment situation, but found no significant effects besides the above mentioned difference between men and women in the impact of bad employment situation on childlessness intentions (results not shown). Thus, controlling for country-level variance in childlessness intentions, we found that poor individual socio-economic resources, measured by lower educational level, low socioeconomic position or not being employed, or for men, employment situation being poor, were associated with an increased risk of intending to remain childless.

In Model III we included country-level factors (Table 3a). Inclusion of these reduced the level 2 variance (variance between countries) substantially. Somewhat surprisingly, country-level unemployment rate was negatively associated with intentions to remain childless. Thus, although the impact of one's own unemployment on childbearing intentions was negative as we had expected, higher unemployment among young adults in a country did not depress individual childlessness intentions. On the other hand, the share of tertiary-level educated women failed to have any significant association with individual childbearing intentions. We had expected that a higher (female) educational level would be related to more liberal norms and awareness of work and family incompatibility and hence to higher odds of intentional childlessness, but found no such effect. Country-level adherence to traditional family values, measured by the importance of children to a marriage, was associated with lower odds of intending to remain childless. Controlling for state-socialist countries (Model IV, Table 3a) made the impact of unemployment rates statistically insignificant. 


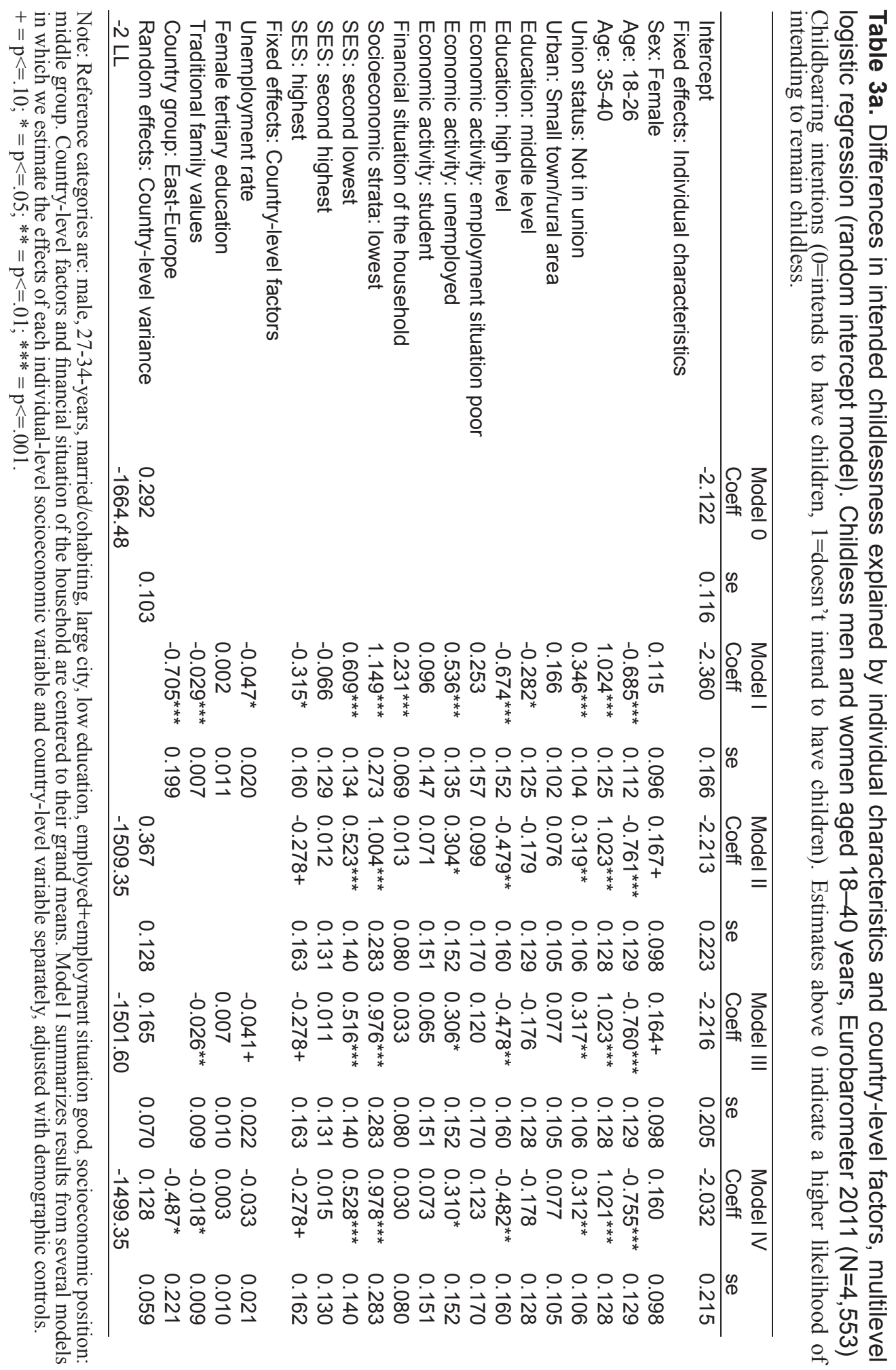


Table $3 \mathrm{~b}$ presents the results for childlessness ideals. The intercept-only model (Model $0)$ shows the country-level variance $(0.434)$, which is statistically significant $(\mathrm{p}<0.01)$. Model II includes all individual-level characteristics at the same time in the model. As was the case with childbearing intentions, gender and place of residence had no significant effect on the odds of preferring childlessness, while increasing age and not living in a union were associated with ideal childlessness (Model II, Table 3b). Educational differences in childlessness ideals were smaller than in intentional childlessness and diminished considerably once other measures of socioeconomic position were included in the model (Model I and Model II). Perceived job uncertainty was not statistically significantly related to preferring a childfree life, while being unemployed or inactive was. Low socioeconomic position was also associated with considering childlessness ideal. However, in contrast to intended childlessness, the impact of socioeconomic position on childlessness ideals was statistically significant only in the second lowest group. In this group, the impact was related to uncertain employment situation and poor financial resources, and controlling for these diminished the negative impact of low socioeconomic position on fertility preferences (Table 3b Model II shows only the final model). Independently, the financial situation of the household was only weakly associated with childlessness preferences (Model I). Once we controlled for other socioeconomic measures, a poor financial situation of the household had no significant effect on preferring childlessness. We again tested for gender differences in the impact of socioeconomic variables, but did not find any statistically significant effects (results not shown).

Of country-level factors, the unemployment rate was significantly associated with fertility ideals (Model III, Table 3b). As with childbearing intentions, women and men were less likely to prefer childlessness in countries with higher levels of unemployment among 15-39-year olds. The effect of unemployment was reduced marginally significant when we controlled for other country-level variables (Model III and IV). Again, a higher level of female tertiary education was not associated with individual fertility ideals, while traditional family values were. Men and women living in countries with a more traditional social climate were less likely to desire childlessness compared to respondents living in countries where family values were less traditional. The positive impact of a traditional value climate on fertility ideals remained even when controlling for the state-socialist countries.

We examined the robustness of our results by excluding uncertain respondents (those who answered 'it depends' or 'don't know' to the question on ideal number of children or 'don't know' to the question on intended number of children) from our analyses. However, this did not change our results markedly, and while some of the effects became somewhat stronger, conclusions drawn on the basis of the statistical significance tests remained the same. 


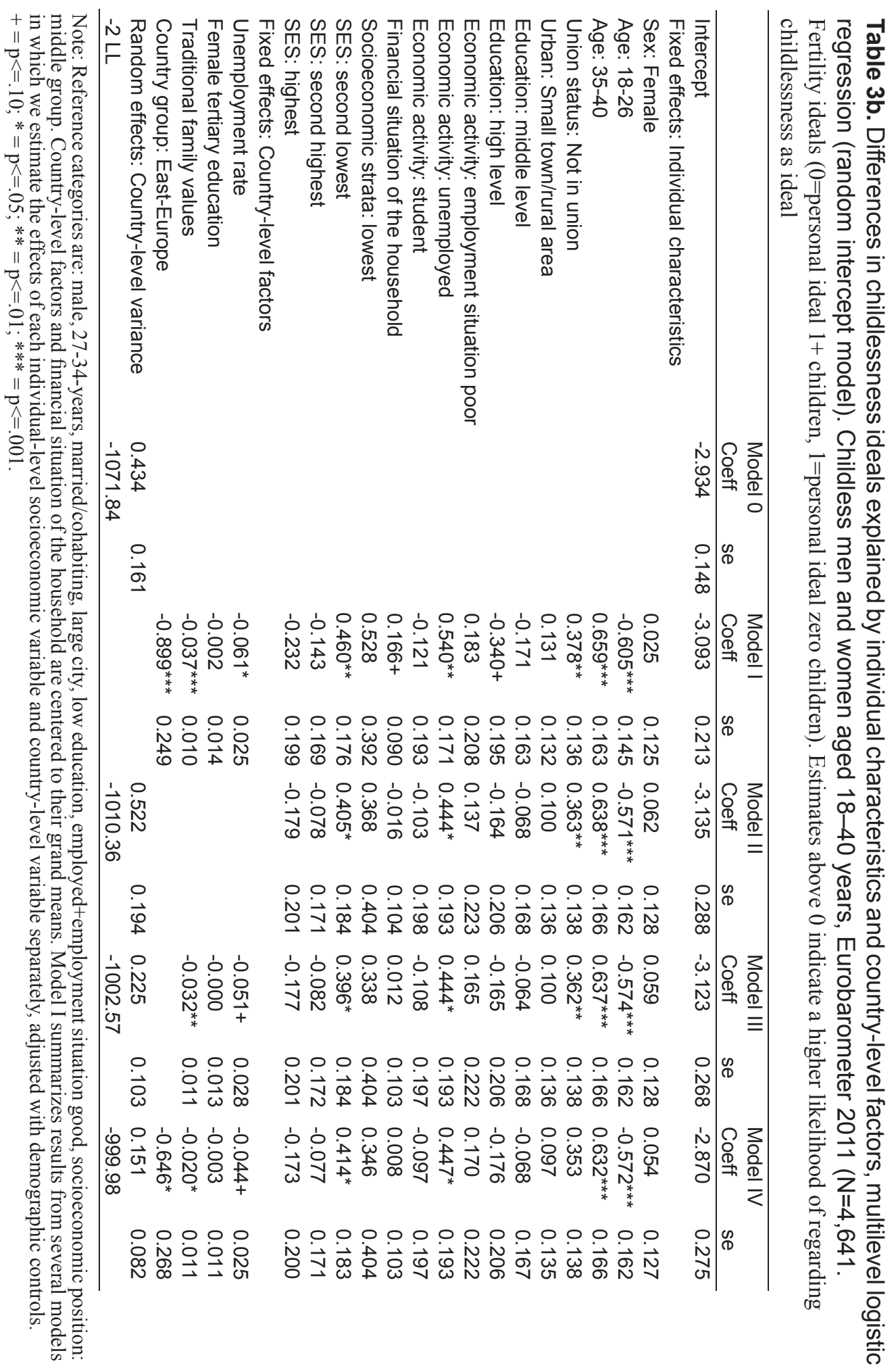


In sum, our findings from multilevel analyses support our expectations that intentional childlessness is related to perceived opportunities and costs of childbearing more than childlessness ideals are. A weaker social position also influenced intentions to enter parenthood through various channels. The negligible effect of the household's financial situation on childlessness intentions once other measures of socioeconomic resources were included in the model may be related to how these variables were measured in the survey. It is possible that self-assessed socioeconomic position captures the effect of financial resources - perceiving household financial resources poor correlated with positioning oneself to lower socioeconomic groups.

Associations between socioeconomic indicators and childlessness ideals were less clear, although it seems that a preference for childlessness was more frequent in the lowest socioeconomic groups, among whom poor economic resources intertwine with unemployment. Given that childlessness as a preferred family form was relatively rare in our sample, however, caution in the interpretation of the results is warranted.

\section{Conclusion}

This article examined childlessness intentions and ideals in Europe using data from three waves of Eurobarometer survey conducted in 2001, 2006 and 2011. Results showed that for most young Europeans childlessness is not based on a deliberate intention or desire to remain childless, but on a temporary postponement of parenthood for various reasons. This is in line with previous studies on fertility trends in Europe (Billari et al. 2006; Sobotka 2004). We also did not discern any apparent increase in ideal or intentional childlessness over the past decade. On average, $4 \%$ of men, and 3\% of women in the age group 18-40 years considered zero children their personal ideal. Considering childlessness a personal ideal was slightly more common in the EU15 countries, with $6 \%$ of men and $4 \%$ of women preferring childlessness, than in many Eastern European countries where it remained below 3\% for both genders. Compared to childlessness preferences, a somewhat higher proportion of young Europeans intend to remain childless. In the age group of $18-40$-year old, $7 \%$ of men and $5 \%$ of women intended to have no children. Once we controlled for differences in the proportions of childless respondents between countries and focused on childbearing intentions among the currently childless, intended childlessness accounted for around $11 \%$ of childlessness among young adults. Again, intentional childlessness was on a higher level among the EU15 countries (14-15\% of currently childless men/women in EU15 intended to remain childless) than in the eastern European countries.

We examined correlates of intentional and ideal childlessness using data from the recent Eurobarometer 2011. Contrary to previous studies, we did not find any significant differences between men and women, or between urban and rural residents in childlessness intentions or ideals. Living in a union appears to be strongly related to 
fertility intentions and desires, in that men and women were more likely to intend to remain childless, or to regard zero children as their preferred family size if they did not have a partner. On the other hand, our study supported previous findings in that existing social norms and values in a given society were found to be associated with individual fertility preferences and intentions (Merz \& Liefbroer 2002). In addition, we found that poor socioeconomic resources influenced childlessness intentions through various ways. Lower educational attainment or lower socioeconomic position, being unemployed or in less secure employment situation were all negatively related to childbearing intentions, while their role was not as clear in explaining childlessness ideals. Particularly in the post-socialist countries, where unemployment is a relatively new phenomenon, employment uncertainty may be perceived more threatening (Murinkó \& Spéder 2009).

The negative effect of poor employment and socioeconomic situation on childbearing intentions did not seem to hold on a country level. It seems that the contextual economic situation does not impede childbearing intentions, when it comes to having a first child. Our results are thus in line with Testa and Basten (2014) who also found little evidence of country-level effects on fertility intentions among childless persons. It is possible, however, that a poor overall economic situation in a country has more influence on later childbearing decisions, i.e. whether to have a second, or a third child (Harknett, Billari \& Medalia 2014; Testa \& Basten 2014; Tanskanen \& Rotkirch 2014).

Our findings suggest that there are at least two demographically distinctive groups in Europe with respect to intentional childlessness. Relatively high rates of intentional childlessness (both desired and intended childlessness) characterize the German-speaking countries Austria, Germany and Switzerland. This group includes also the Netherlands and Luxembourg, and perhaps also Belgium, a country with only slightly lower rates of intended childlessness. In contrast, and despite profound cultural, economic and political changes, the eastern European countries still exhibit very low levels of intentional or ideal childlessness. This is one of the aspects which question the suitability of the concept of the second demographic transition in describing demographic trends in post-socialist countries (Coleman 2004). The group of low intended childlessness also includes France and Ireland, both of which have also shown high overall fertility levels during recent decades, although Ireland also has high childlessness (Miettinen et al. 2014). It is possible that the influence of Catholicism in these two countries partly explains why only a small fraction of young adults are deliberately choosing childlessness, although the relatively high levels of intended childlessness in Italy and Spain seem to refute this hypothesis.

The rest of the countries form a diverse group, comprising countries from southern, northern, and western Europe with intentional childlessness rates falling between the two extremes. Among them, southern European countries appear to have gradually 
moved from low levels of intentional childlessness in the beginning of the 2000s towards the middle group with average rates of intentional childlessness, whereas countries from the north have exhibited more stable, average-level rates of intended childlessness over the past decade. Although we have here included the UK in the middle-level group, recent data from EB2011 suggests that rates of intended childlessness in the UK may be moving towards the higher rates observed in some centralEuropean countries.

Among the limitations of our study is the cross-sectional nature of the Eurobarometer data. For instance, although older age and not living in a union were consistently found to decrease childbearing intentions and desires, a cross-sectional study cannot determine whether this is due to selection - older childless respondents are a more selected group - or from gradual adjustment of intentions and ideals to suit one's own life situation. Some postponers, or people who originally considered themselves only temporarily childless but have run out of time and can no longer have children, or failed in finding a suitable partner, may retrospectively re-interpret their previous preferences and present themselves as always having been voluntarily "childfree" (Kneale \& Joshi 2008; Gillespie 2003; Heaton, Jacobson \& Holland 1999).

Harmonized Eurobarometer data allowed us to conduct an international comparison but the small national sample sizes prevent more comprehensive multivariate analyses. While multilevel analyses provide a possibility to include country-level characteristics into the analyses, larger data sets would allow investigations of cross-level interactions as well as gender- and age-specific effects of factors associated with childlessness intentions. Although we did not find any strong evidence of increasing rates of intentional childlessness, it would be valuable to do a more in-depth study of childlessness choices among young adults in their late twenties or early thirties to be able to detect emerging trends in voluntary childlessness. In addition, since the EB2011 data includes only a limited number of background characteristics of the respondents, we were only able to pay attention to socioeconomic resources in explaining differences in childbearing intentions or ideals. In the future it would be necessary to include information on religiousness, family values or other attitudes of the respondents to be able to explore to what extent childlessness intentions or ideals are driven by structural or normative forces.

\section{Acknowledgements}

The research leading to these results has received funding from the European Union's Seventh Framework Programme (FP7/2007-2013) under grant agreement no. 320116 for the research project FamiliesAndSocieties and from the Academy of Finland (research project 266898). 


\section{References}

Abma, J.C. \& Martinez, G.M. (2006). Childlessness among older women in the United States: Trends and profiles. Journal of Marriage and Family 68: 1045-1056

Berrington, A. (2004). Perpetual postponers? Women's, men's and couple's fertility intentions and subsequent fertility behaviour. Population Trends 117: 9-19.

Billari, F.C., Liefbroer, A.C. \& Philipov, D. (2006). The postponement of childbearing in Europe: Driving forces and implications. Vienna Yearbook of Population Research 2006: $1-17$.

Bongaarts, J. (2001). Fertility and reproductive preferences in post-transitional societies. Population and Development Review, Supplement to Vol. 27: 260-281.

Carmichael, G.A. \& Whittaker, A. (2007). Choice and circumstance: Qualitative insights into contemporary childlessness in Australia. European Journal of Population 23: 111-143.

Coleman, D. (2004). Why we don't have to believe without doubting in the "Second Demographic Transition" - some agnostic comments. Vienna Yearbook of Population Research 2004: 11-24.

Dye, J.L. (2010). Fertility of American women 2008. U.S. Census Bureau, Current Population Reports P20-563.

Frejka, T. (2008). Parity distribution and completed family size in Europe: Incipient decline of the two-child family model? Demographic Research 19(4): 47-72.

Gillespie, R. (2003). Childfree and feminine: Understanding the gender identity of voluntarily childless women. Gender and Society 17(1): 122-136.

Goldstein, J., Lutz, W., \& Testa, M.R. (2003). The emergence of sub-replacement family size ideals in Europe. Population Research and Policy Review 22(5): 479-496.

Hagewen, K.J. \& Morgan P.S. (2005). Intended and ideal family size in the United States, 1970-2002. Population and Development Review 31(1): 507-527.

Hakim, C. (2000). Work-lifestyles choices in the 21st century: Preference theory. Oxford: Oxford University Press.

Hakim, C. (2002). A new approach to explaining fertility patterns: Preference theory. Population and Development Review 29(3): 349-373.

Harknett, K., Billari, F. \& Medalia, C. (2014). Do family support environments influence fertility? Evidence from 20 European countries. European Journal of Population 30: 1-33.

Heaton, T.B., Jacobson, C.K. \& Holland K. (1999). Persistence and change in decisions to remain childless. Journal of Marriage and Family 61(2): 531-539.

Keizer, R., Dykstra, P.A. \& Jansen, M.D. (2007). Pathways into childlessness: Evidence of gendered life course dynamics. Journal of Biosocial Science 40: 863-878.

Kiernan, K. (1989). Who remains childless? Journal of Biosocial Science 21(4): 387-398.

Kneale, D. \& Joshi, H. (2008). Postponement and childlessness: Evidence from two British cohorts. Demographic Research 19: 1935-1964.

Kohler, H-P., Billari F. \& Ortega, J.A. (2002). The emergence of lowest-low fertility in Europe during the 1990s. Population and Development Review 28: 641-680. 
Lainiala, L. (2012). Toiveesta toteutukseen [From intention to realization of childbearing]. E44. Väestöliitto Population Research Institute.

Letherby, G. (1999). Other than mother and mothers as others: The experience of motherhood and non-motherhood in relation to 'infertility' and 'involuntary childlessness'. Women's Studies International Forum 22(3): 359-372.

Lutz, W., Skirbekk, V. \& Testa, M.R. (2005). Low-fertility trap hypothesis: forces that may lead to further postponement and fewer births in Europe. European Demographic Research Papers 4. Vienna Institute of Demography.

McAllister, F. \& Clarke, L. (1998). Choosing Childlessness. London: Family Policy Studies Centre.

Merz, E.M. \& Liefbroer, A.C. (2012). The attitude toward voluntary childlessness in Europe: cultural and institutional explanations. Journal of Marriage and Family 74(3): 587-600.

Miettinen, A. (2012). Voluntary or involuntary childlessness? Socio-demographic factors and childlessness intentions among childless Finnish men and women aged 25-44. Finnish Yearbook of Population Research XLV 2010: 5-24

Miettinen, A., Rotkirch, A., Szalma, I., Donno, A. \& Tanturri, M.L. (2014). Increasing childlessness in Europe: Time trends and country differences. Working Paper, Families \& Societies; forthcoming).

Mills, M. \& Blossfeld, H-P. (2005). Globalization, uncertainty and changes in early life courses. In: H-P. Blossfeld, E. Klijzing, M. Mills, and K. Kurz (Eds.) Globalization, Uncertainty and Youth in Society, pp. 1-24. New York: Routledge.

Murinkó, L. \& Spéder, Zs. (2010). Attitudes towards unmarried cohabitations in Europe. Conference Presentation. European Population Conference 1.-4.9. 2010, Vienna.

Park, K. (2002). Stigma management among the voluntary childlessness. Sociological Perspective 45(1): 21-45.

Park, K. (2005). Choosing childlessness: Weber's typology of action and motives of the voluntarily childless. Sociological Inquiry 75(3): 372-402.

Parr, N. (2005). Family background, schooling and childlessness in Australia. Journal of Biosocial Science 37: 229-243.

Regushevskaya, E., Hemminki, E., Klemetti, R., Rotkirch, A., Karro, H., HaavioMannila, E., \& Miettinen, A. (2013). Postponing births - Comparing reasons among women in St. Petersburg, Estonia and Finland. Finnish Yearbook of Population Research XLVIII: $127-145$.

Rindfuss, R.R., Morgan, S.P. \& Swicegood, G. (1988). First births in America: Changes in the timing of parenthood. Studies in demography. Berkeley (CA): University of California Press.

Rowland, D.T. (2007). Historical trends in childlessness. Journal of Family Issues 28(10): 1311-1337.

Schoen, R., Astone, N.M., Kim, Y.J., Nathanson, C.A. \& Fields, J.M. (1999). Do fertility intentions affect fertility behavior? Journal of Marriage and the Family 61(3): 790-799.

Smallwood, S. (2002). New estimates of trends in births by birth order in England and Wales. Population Trends 108: 32-48. 
Smallwood, S. \& Jeffries, J. (2003). Family building intentions in England and Wales: Trends, outcomes and interpretations. Population Trends 112: 15-25.

Sobotka, T. (2009). Sub-replacement fertility intentions in Austria. European Journal of Population 25: 387-412.

Sobotka, T. (2004). Postponement of childbearing and low fertility in Europe. University of Groeningen (Netherlands): Dutch University Press.

Sobotka, T. \& Beaujouan, E. (2014). Two is best? The persistence of a two-child family ideal in Europe. Population and Development Review 40(3): 391-419.

Spéder, Zs. \& Kapitàny, B. (2014) Failure to realize fertility intentions: A key aspect of the post-communist fertility transition. Population Research and Policy Review 33(3): 393-418.

Szalma, I. \& Takács, J. (2012). A gyermektelenséget meghatározó tényezők Magyarországon [Factors influencing childlessness in Hungary]. Demográfia 55(1): 44-68.

Tanskanen, A. \& Rotkirch, A. (2014) The impact of grandparental investment on mothers' fertility intentions in four European countries. Demographic Research 31(1): $1-26$.

Tanturri, M.L. \& Mencarini, L. (2008). Childless or childfree? Paths to voluntary childlessness in Italy. Population and Development Review 34(1): 51-77.

Testa, M.R. (2006). Childbearing preferences and family issues in Europe. Special Eurobarometer. Luxembourg: European Commission. Available from: $\leq \mathrm{http}: / /$ ec.europa.eu/public_opinion/archives/ebs/ebs_253 en.pdf $>$

Testa, M.R. (2012). Family Sizes in Europe: Evidence from the 2011 Eurobarometer Survey. European Demographic Research Papers 2. Vienna: Vienna Institute of Demography of the Austrian Academy of Sciences.

Testa, M.R. \& Basten, S. (2014). Certainty of meeting fertility intentions declines in Europe during the 'Great Recession'. Demographic Research 31(23): 687-734.

Veevers, J. (1980). Childless by choice. Toronto \& Vancouver: Butterworth co.

Weston, R. \& Qu, L. (2001). Men's and women's reasons for not having children. Family Matters 58: 10-15. 